\title{
EVALUASI PROGRAM BEASISWA KOMUNITAS ADAT TERPENCIL DI DINAS PENDIDIKAN KABUPATEN BENGKALIS
}

\author{
Yeyen Suhana ${ }^{1)}$ \\ Azhar ${ }^{2)}$ \\ Rr. Sri Kartikowati ${ }^{3}$ \\ ${ }^{1)}$ Post Graduate Student of Riau University \\ ${ }^{2)}$ Lecturer of Education Management Study Programme PPs University of Riau \\ ${ }^{3}$ Lecturer of Education Management Study Programme PPs University of Riau
}

\begin{abstract}
The research aims to get definition of implementation scholarship programe of indigenous community in education department Bengkalis regency. Especially : (1) The scholarship programe of indigenous communities; (2) Focus of programe input the expediency human resource, facilities and infrastructure, fund and programe budget; (3) The process program include the time of implementation programe, the mechanism of implementation program, the factors inhibitors of implementation program and organization of partnership; (4) The product of programe include quality and quantity obtained from organizers scholarship program of indigenous communities and indigenous community's student. The search method is evaluation search use of qualitative approachment and evaluation model used is CIPP ( Context, Input, Process, and Product). The technics data are documentation, interview, observation. The Source of data research are organizers, executor committe and comitte of verification of data, presentation of data, and conclusion. The data results are : (1) the context the program is said to be good because it is one of communities; (2) In input aspect is said to be good to expendiancy of human resource is the selection of members of the communities. While from the aspect of facilities and infrastructure have not complied with objective standart of indequate feasibility; (3) the program implemtation process is said to be less good because aspects only one that matches the feasibility standart. While from implmentation of time. Programe implementation mechanism is not suitable with guidelines so causing an inhibition of implementation; (4) the results of program implementation is said to be good, quantity and quality participants.
\end{abstract}

Key words : Evaluation, the progame scholarship of indigenous communities: Context, Input, Process, Product

ABSTRAK: Penelitian ini secara umum bertujuan untuk mendapatkan gambaran tentang penyelenggaraan Program Beasiswa Komunitas Adat Terpencil di Dinas Pendidikan Kabupaten Bengkalis. Khususnya tentang: (1) Konteks Program Beasiswa Komunitas Adat Terpencil; (2) Input Program yang difokuskan pada kelayakan sumber daya manusia, sarana dan prasarana, dana dan anggaran program; (3) Proses program yang meliputi waktu pelaksanaan program, mekanisme pelaksanaan program, faktor-faktor penghambat dalam pelaksanaan, penyelenggaraan kemitraan; (4) Produk dari pelaksanaan program meliputi kuantitas dan kualitas yang di peroleh penyelenggara program beasiswa KAT dan mahasiswa Komunitas Adat Terpencil. Metode penelitian ini merupakan penelitian evaluasi yang menggunakan pendekatan kualitatif dan model evaluasi yang digunakan adalah CIPP (context, input, process, dan product). Teknik pengumpulan data menggunakan dokumentasi, wawancara dan observasi. Sumber data penelitian adalah penyelenggara, panitia pelaksana dan panitia tim verifikasi, mahasiswa. 
Kemudian analisis data meliputi: pengumpulan data, reduksi data, penyajian data, dan penarikan kesimpulan. Hasil penelitian : (1) Konteks program dikatakan baik karena merupakan salah satu program untuk menunjang perbaikan mutu pendidikan di kalangan komunitas adat terpencil; (2) dari aspek input dikatakan baik pada kelayakan sumber daya manusia yaitu pemilihan anggota panitia yang merata serta kesiapan pengetahuan program pada seluruh panitia. Sedangkan dari aspek sarana dan prasarana belum memenuhi standar objektif kelayakan yaitu sarana dan prasarana yang kurang memadai; (3) proses pelaksanaan program dikatakan kurang baik karena dari empat aspek hanya satu yang sesuai standar kelayakan.sedangkan dari waktu pelaksanaan, mekanisme pelaksanaan program tidak sesuai dengan pedoman sehingga menimbulkan penghambat dalam pelaksanaan; (4) hasil dari pelaksanaan program dikatakan baik, kuantitas dan kualitas peserta.

Kata Kunci : Evaluasi, Program Beasiswa Komunitas Adat Terpencil: Context, Input, Process, Product

\section{PENDAHULUAN}

Kabupaten Bengkalis memiliki program beasiswa yaitu beasiswa kepada siswa tamatan SMA/SMK Sederajat.Program beasiswa ini sudah berjalan dari tahun 2012 hingga sekarang. Beasiswa ini untuk meringankan beban mahasiswa dalam menempuh masa studi, khususnya dalam masalah biaya semester. Pemberian beasiswa dilakukan secara selektif sesuai dengan jenis beasiswa yang diadakan.

Berdasarkan Juknis yang dibuat oleh dinas pendidikan kab. bengkalis terdapat 3 jenis program beasiswa. 1) beasiswa prestasi, 2) beasiswa non akademik, 3) beasiswa komunitas adat terpencil (KAT). Beasiswa ini di mulai dari pertama masuk kuliah dengan menggunakan prestasi disekolah SMA/SMK, dan untuk beasiswa khusus yaitu beasiswa non akademik di nilai berdasarkan prestasi mendapat penghargaan ditingkat nasional seperti lomba karya tulis, olahraga, kesenian dan keagamaan.

Khusus untuk beasiswa KAT yang menjadi kriterianya adalah mahasiswa yang merupakan lulusan dari SMA, SMK, dan MA di Kabupaten Bengkalis. Dan berasal dari keluarga komunitas adat terpencil hal ini Sesuai dengan surat pemberitahuan nomor: 422.5/DISDIK/X/2012/ 143.

Beasiswa harus diberikan kepada penerima yang layak dan pantas untuk mendapatkannya. Kriteria umum yang telah diterapkan oleh pihak Dinas Pendidikan Kab. Bengkalis masing-masing memiliki parameter-parameter yang lebih detail. Penerapannyapun bergantung kepada sifat kebeasiswaanya ada beasiswa yang mengutamakan mahasiswa tidak mampu dan ada pula beasiswa yang tidak melihat latar belakang ekonomi.

Pada penelitian ini beasiswa yang akan dibahas yaitu mengenai beasiswa KAT atau Komunitas Adat Terpencil. Dimana beasiswa ini merupakan beasiswa yang diberikan kepada siswa/i dari keluarga suku asli dan terpencil yang lulus SMA/SMK yang melanjutkan pendidikan ke Perguruan Tinggi. Komunitas Adat Terpencil (KAT) atau yang selama ini lebih dikenal dengan sebutan masyarakat terasing adalah kelompok sosial budaya bersifat lokal dan terpencar serta kurang atau belum terlibat dalam jaringan dan pelayanan baik sosial, ekonomi, maupun politik.

Keputusan Presiden Republik Indonesia nomor 111 Tahun 1999 tentang Pembinaan Kesejateraan Sosial Komunitas Adat Terpencil pasal (5) ayat (1) menyatakan bahwa pelaksanaan pembinaan kesejahteraan sosial komunitas adat terpencil dilakukan dalam bidang : Pemukiman, Administrasi kependudukan, Kehidupan beragama, Pertanian, Kesehatan, Pendidikan, dan Bidang lainnya.

Sejauh ini Tata kelola Beasiswa Komunitas Adat Terpencil (KAT) di Dinas Pendidikan Kab. Bengkalis dirasakan berbeda dengan beasiswa lainnya. Seperti dalam hal sosialisasi, rekruitment, proses penerimaan, persyaratan yang tidak 
sepesifik sampai pada keberlanjutannya. Jika beasiswa prestasi dan non akademis jelas menggunakan nilai prestasi dan sertifikat penghargaan maka untuk beasiswa KAT menggunakan profil pemohon yang berasal dari keluarga komunitas adat terpencil. Hal ini dibuktikan dengan dilengkapinya surat keterangan dari lembaga adat.

Melalui survey yang peneliti lakukan didaerah terpencil seperti Pulau Rupat Utara, Pulau Rupat dan kecamatan lainnya tepatnya 6 bulan yang lalu, diperoleh informasi bahwa masyarakat belum mengerti untuk siapa beasiswa ini diberikan, sosialisasi juga dianggap tidak efektif hal ini berkaitan dengan persyaratan melampirkan Surat Keterangan berasal dari Suku Adat Terpencil (KAT) yang di keluarkan oleh Batin Atau Ketua/Penghulu Adat bagi mahasiswa yang berasal dari KAT sementara lembaga itu sendiri tidak ada di daerah mereka. Jadi banyak hal yang ingin dimintai penjelasan.

Faktanya di Kabupaten Bengkalis banyak sekali anak-anak dari suku pedalaman yang berhak menerima. Hal ini telah disampaikan oleh Bupati Bengkalis pada Pidatonya saat menghadiri acara wisuda salah satu perguruan tinggi di Bengkalis. tapi syarat administrasi membuat mereka kesulitan untuk mengikuti program beasiswa tersebut. Fenomena ini menjadi semakin memprihatinkan disaat melihat penerima beasiswa KAT di domisili dari Kecamatan Mandau, Kecamatan Pinggir. Kecamatan mandau memiliki sebuah lembaga suku Adat terpencil dari ras Batak begitu juga kecamatan pinggir jelasnya dari 8 Kecamatan di Kabupaten Bengkalis hanya dua Kecamatan yang merasakan program dari Pemerintah tersebut. Sejalan dengan fenomena yang penulis temui dilapangan, penulis tertarik untuk meneliti lebih jauh tentang manajemen Beasiswa komunitas adat terpencil (KAT) dengan judul penelitian "EVALUASI PROGRAM BEASISWA KOMUNITAS ADAT TERPENCIL (KAT) DI DINAS PENDIDIKAN KABUPATEN BENGKALIS.

\section{CIPP Evaluation Model}

Model evalusi yang digunakan dalam penelitian ini adalah model evaluasi CIPP oleh Stufflebeam, dan kawan-kawan pada tahun 1967 di Ohio State University. Kemudian dikembangkan oleh Gilbert six (1980) yang menambahkan komponen ‘o’ dalam model CIPP sehingga menjadi CIPPO. Namun namanya hingga kini tetap model evaluasi CIPP sekalipun ada penambahan komponen 'O'.Penjabaran CIPP dalam penelitian ini adalah conteks, input, process, product dan outcome.

Stufflebeam mendefinisikan model CIPP sebagai "The CIPP model has a strong orientation to service and the principles of a free society ....clarify their needs for services, asses and help guide effective implementation of services and ultimately assess the service's merit, worth, significance, and probity." (model CIPP memiliki orientasi yang kuat untuk layanan dan prinsip-prinsip masyarakat bebas.... menjelaskan kebutuhan layanan, memperoleh informasi pengguna dalam merancang program responsif dan layanan lainnya, sebagai panduan membantu pelaksanaan layanan yang efektif dan akhirnya menilai jasa layanan, kelayakan, signifikansi,dan kejujuran). Arikunto mendefinisikan model evaluasi CIPP sebagai model evalusi yang memandang program yang dievaluasi sebagai sebuah sistem. Sedangkan Sudjana menjelaskan model evaluasi CIPP adalah model evaluasi program yang terpusat untuk pengambilan keputusan sehingga model ini tepat digunakan untuk evaluasi program pendidikan non formal yang sistematik mencakup komponen, process dan tujuan program.

Context adalah dasar evaluasi yang bertujuan menyediakan alasan-alasan (rationale) dalam menentukan tujuan (Baline R. Worthern \& James R. Sanders: 1979).Karenanya upaya yang dilakukan evaluator dalamevaluasi konteks ini ialah memberikan gambaran dan rincianterhadap lingkungan, kebutuhan dan tujuan (goal).Stufflebeam (1983) menyatakan evaluasi konteks sebagai fokus institusi yang mengidentifikasi peluang dan menilai 
kebutuhan.Kebutuhan dalam hal ini dirumuskan sebagai suatu kesenjangan (discrepancy view) antara kondisi nyata (reality) dengan kondisi yang diharapkan (ideality).Evaluasi konteks juga mendiagnostik suatu kebutuhan yang selayaknya tersedia sehingga tidak menimbulkan kerugian jangka panjang (Isaac \& Michael: 1981).

Input adalah sarana / modal / bahan dan rencana strategis yang ditetapakan untuk mencapai tujuan - tujuan pendidikan. Jadi evaluasi input meliputi analisis personal yang berhubungan dengan bagaimana penggunaan sumber-sumber yang tersedia, alternative strategi yang harus dipertimbangkan untuk mencapai tujuan dalam suatu kegiatan atau program. Mengidentifikasi dan menilai kapabilitas suatu system, alternative rencana dan strategi program, desain prosedur untuk melaksanakan kegiatan atau program, pembiayaan, waktu dan jadwal Komponen evaluasi masukan meliputi : 1) Sumber daya manusia, 2) Sarana dan peralatan pendukung, 3) Dana atau anggaran, dan 4) Berbagai prosedur dan aturan yang diperlukan.

Process, menurut Worthen dan Sanderrs (1981 : 137) evaluasi pendidikan menekankan tujuan yaitu: 1) Do detect or predict in procedurd design or its implementation during implementation stage, 2)To provide information for programed decisions and 3)To maintain a record of the procedure as it occurs. Dari pendapat diatas dapat disimpulakan secara terperinci bahwa dalam proses ini diarahkan untuk mengetahui seberapa jauh kegiatan yang dilaksanakan, apakah pelaksanaanya sesuai dengan rencana atau tidak. Evaluasi proses juga digunakan untuk mendeteksi atau memprediksi rancanagan prosedur atau rancanagan pelaksanaan selama tahap yang dikerjakan, menyediakan informasi untuk keputusan kegiatan atau program dan sebai rekaman atau arsip prosedur yang telah terjadi.

Product, menurut Sugiono evaluasi produk atau output terkait dengan evaluasi terhadap hasil yang dicapai dari suatu program. Evaluasi output digunakan untuk menjawab beberapa pertanyaan sebagai berikut:
1. Seberapa jauh tujuan program tercapai?

2. Program apakah yang tercapai dengan hasil yang tinggi dan rendah?

3. Bagaimana tingkat kepuasan orang - orang yang dikenai sasaran pelaksanaan program?

4. Apakah program tercapai tepat waktu?

5. Apakah dampak positif dan negative program tersebut?

6. Apakah program perlu dilanjutkan dengan revisi atau tidak dilanjutkan?.

\section{METODOLOGI PENELITIAN}

Bedasarkan tujuan penelitian ini, maka peneliti menggunakan metode penelitian kualitatif. Sugiyono menjelaskan penelitian kualitatif adalah proses eksplorasi dan memahami makna pelaku individu dan kelompok, menggambarkan masalah sosial atau masalah kemanusiaan. Meneliti pada kondisi objek yang alamiah, dimana peneliti adalah sebagai instrumen purposivedan snowball, analisis data bersifat kualitatif dan hasil kualitatif lebih menekankan makna dari pada generalisasi.

Penelitian kualitatif dilaksanakan dalam upaya memahami situasi tertentu dengan pendekatan studi kasus. Wirawan mengatakan "studi kasus adalah studi tentang kasus atau unit analisis tertentu. Pendekatan kualitatif dipandang lebih relevan untuk digunakan di dalammengamati dan menganalisa fenomena - fenomena pada Program Beasiswa Komunitas Adat Terpencil (KAT)di Dinas Pendidikan Kab. Bengkalis.

Pendekatan kualitatif dilaksanakan sebagai upaya menggali informasi secara langsung melalui interaksi dengan nara sumber (informasi). Selanjutnya penulis memberikan analisis ilmiah mengenai program manajemen Beasiswa Komunitas Adat Terpencil (KAT) di Dinas Pendidikan Kab. Bengkalis.

Berdasarkan uraian di atas maka yang menjadi sumber data penelitian ini adalah sebagai berikut:

1. Data primer: (a) seluruh situasi, kondisi dan lingkungan sebagai tempat berjalannya program beasiswa komunitas adat terpencil. 
Data yang diperoleh dengan serangkaian kegiatan yakni observasi dan wawancara.

2. Data sekunder diperoleh melalui penelaahan terhadap dokumen pribadi, resmi kelembagaan, referensi-referensi atau peraturan (literatur laporan, tulisan dan lainlain yang memiliki relevansi dengan fokus permasalahan penelitian).

Data yang dikumpulkan dalam penelitian ini adalah sesuai dengan fokus penelitian yaitu evaluasi program beasiswa Komunitas Adat Terpencil (KAT) di Dinas Pendidikan Kab. Bengkalis. Penulis mengumpulkan data sebanyak mungkin dari situasi sosial yang diteliti, yaitu meliputi aspek tempat, kebijakan, prilaku dan aktifitas. Sumber data merupakan hal yang pokok dan utama dalam penelitian karena sumber data merupakan bahan yang akan diteliti.

Sumber data primer diperoleh dari pihak yang terlibat dalam penyelenggaraan Beasiswa Komunitas Adat Terpencil (KAT) di Kab. Bengkalis yaitu Kepala Dinas Pendidikan atau pejabat pelaksana teknis kegiatan, pengelola atau pelaksana kegiatan, Mahasiswa, masyarakat. Sedangkan sumber data sekunder diperoleh dari arsip dan dokumen yang berkaitan dengan fokus penelitian, yaitu visi dan misi, Buku dan panduan teknis, surat edaran atau surat resmi Dinas Pendidikan Kab. Bengkalis. Laporan akhir dan foto kegiatan penyelenggara Beasiswa Komunitas Adat Terpencil

Penelitian ini dilakukan melalui proses pengumpulan data - data yang berlangsung di Dinas Pendidikan Kab. Bengkalis, yakni: wawancara yang bertujuan untuk memperoleh informasi yang lebih mendalam perihal Bagaimana Pelaksanaan Manajemen manajemen Beasiswa Komunitas Adat Terpencil (KAT) di Dinas Pendidikan Kab. Bengkalis.

Cara pengambilan sampel yang digunakan (purposive sampling) dan bersifat sampel bola salju. Penentuan sampel atau informan sumber data masih bersifat sementara dan akan berkembang kemudian setelah penulis dilapangan.Sampel bola salju (snowball sampling) sering juga disebut sampel jaringan (network sampling) adalah penentuan sampel dengan menggunakan partisipan lain untuk melengkapi informasi dari partisipasi terdahulu. Sampel bola salju digunakan untuk memperluas informasi yang ditemui namun semakin banyak informasi yang masuk dan makin mengembangkan hipotesis kerja, maka sampel dipilih atas dasar fokus penelitian. Jika sudah terjadi pengulangan informasi maka penarikan sampel akan dihentikan.

Selanjutnya dokumentasi sebagai bahan pengumpulan data penelitian sehingga lebih memperkuat data yang telah ada berupa bukti fisik yang diperoleh oleh peneliti dalam menganalisis Program Manajemen Beasiswa Komunitas Adat Terpencil (KAT) berupa catatan publik dan pribadi yang diperolehpeneliti kualtatif tentang situs atau pastisipan penelitian seperti dokumen hasil wawancara, dokumen yangadministrasi dinas, data total penerima dan dokumen lain yang mendukung penelitian. Dokumentasi yang menjadi bahan bukti fisik yang diperlukan berkaitan dengan progam yang dilaksanakan.

Selanjutnya melakukan observasi untuk dapat berinteraksi penuh dalam situasi sosial dengan subjek penelitian. Teknik ini digunakan untuk mengamati, memahami peristiwa secara cermat, mendalam dan berfokus terhadap subjek penelitian baik dalam suasana formal maupun santai tentang subjek penelitianPelaksanaan program Manajemen Beasiswa Komunitas Adat Terpencil (KAT).

\section{HASIL DAN PEMBAHASAN}

Berdasarkan data hasil penelitian yang peneliti peroleh, baik melalui hasil wawancara, observasi maupun studi dokumentasi maka peneliti akan melakukan pembahasan mengenai evaluasi pelaksanaan program beasiswa komunitas adat terpencil di Dinas Pendidikan Kabupaten Bengkalis.

Penelitian ini menggunakan model evaluasi CIPP yang dikembangkan pertama kali oleh Stufflebeam sebagai standar untuk mengevaluasi, dan membuat keputusan tindak lanjut akan 
pelaksanaan program beasiswa komunitas adat terpencil di Dinas Pendidikan Kabupaten Bengkalis. Hasil penelitian yang peneliti dapatkan adalah sebagai berikut :

1. Evaluasi konteks pelaksanan program beasiswa komunitas adat terpencil di Dinas Pendidikan Kabupaten Bengkalis.

Evaluasi konteks akan mengukur seberapa jauh perencanaan yang dirancang oleh penyelenggara beasiswa komunitas adat terpencil untuk menyukseskan tujuan yang ingin dicapai. Tolak ukurnya adalah buku panduan teknis pelaksanan program beasiswa khusus tahun 2016.

a. Latar belakang

Dasar terselenggaranya program beasiswa komunitas adat terplencil di Dinas Pendidikan Kabupaten Bengkalis adalah berdasarkan keinginan dan motivasi pemerintah Kabupaten Bengkalis untuk menjadikan Bengkalis sebagai Kota Pendidikan. karenaSelain itu pertimbangan penyelenggara program beasiswa KAT ini adalah untuk meningkatkan kualitas kesejahtraan masyarakat komunitas adat terpencil. Karena kabupaten adalah daerah yang masih memiliki masyarakat tertinggal yang disebut dengan komunitas adat terpecil.

Kondisi ekonomi keluarga yang rendah, pengetahuan orang tua yang minim membuat lulusan SMA/SMK dari golongan komunitas adat terpencil tidak dapat mendaftar pada satuan pendidikan yang lebih tinggi sementara mereka mempunyai keinginan yang sama dengan lulusan sekolah lain untuk bisa melanjutkan pendidikan ke salah satu universitas. Karena itulah Pemerintah Daerah yang diwakili oleh Dinas Pendidikan Kabupaten Bengkalis memutuskan menyelenggarakn beasiswa komunitas adat terpencil (KAT). Dan bekerjasama dengan pihak-pihak terkait untuk mensukseskan jalannya program beasiswa KAT.

Relevansinya pada penelitian ini dengan mahasiswa komunitas adat terpencil melalui program beasiswa komunitas adat terpencil adalah terkait dalam peraturan menteri sosial
Republik Indonesia nomor 09 tahun 2012 tentang pemberdayaan komunitas adat terepencil dengan pasal I menerangkan bahwa pemberdayaan Sumber Daya KAT adalah rangkaian kegiatan yang bersifat bimbingan dan pemantapan dalam rangka meningkatkan kemampuan warga KAT dibidang tertentu agar mereka mampu melakukan perubahan sosial kearah kehidupan dan penghidupan yang lebih baik melalui penggalian dan pengembangan potensi.

a. Tujuan dan sasaran program beasiswa komunitas adat terepncil

Penyelenggaraan program beasiswa komunitas adat terpencil sesuai petunjuk teknis beasiswa khusus tahun 2016 menyatakan bahwa, tujuan umum dari pelaksanaan program beasiswa ini adalah meningkatkan sumber daya manusia yang berkualitas dan berdaya saing, dan tujuan khusus adalah membantu meringankan biaya pendidikan yang ditanggung oleh orang tua, membina siswa yang berasal dari komunitas adat terpencil untuk memperoleh pendidikan sampai keperguruan tinggi. Dan sasaran dari pelaksanaan program beasiswa komunitas adat terpencil adalah anak didik lulusan SMA/SMK dari komunitas adat terpencil untuk tahun pertama, tahun kedua, ketiga maupun tahun keempat.

Evaluasi konteks tujuan dan sasaran program beasiswa komunitas adat terpencil di Dinas Pendidikan Kabupaten Bengkalis terlihat dari minat yang dimiliki oleh mahasiswa KAT untuk mengajukan permohonan beasiswa. Dengan minat yang begitu besar mahasiswa KAT mengikuti program beasiswa telah memenuhi akan tujuan dan sasaran diselenggarakannya program beasiswa tersebut.namun penyelenggara dan panitia perlu menganalisis kembali berlangsungnya program beasiswa komunitas adat terpencil agar benar-benar sesuai atau relevan dengan tujuan yang hendak di capai.

2. Evaluasi input program beasiswa komunitas adat terpencil di Dinas Pendidikan Kabupaten Bengkalis

Evaluasi input merupakan pengukuran seberapa jauh kemampuan sistem lembaga 
penyelenggara dan peserta pelaksana untuk menyelenggarakan program beasiswa komunitas adat terpencil.tolak ukur evaluasi input adalah petunjuk teknis beasiswa khusus tahun 2016.

\section{a. Kelayakan Sumber Daya Manusia}

Pemilihan panitia adalah hal yang harus dilakukan oleh pejabat pelaksana teknis kegiatan sebelum memulai proses program beasiswa komunitas adat terpencil. Juknis mengatur, verifikasi dan seleksi dilakukan oleh tim seleksi yang ditunjuk berdasarkan SK kepala Dinas Pendidikan Kabupaten Bengkalis. Ia bertugas Meneliti persyaratan administrasi calon penerima beasiswa,Melakukan verifikasi dan seleksi calon penerima beasiswa, Mengusulkan daftar calon penerima beasiswa ke Dinas Pendidikan Kabupaten Bengkalis, Menyeleksi calon penerima beasiswa sesuai kriteria, Mengusulkan daftar calon penerima beasiswa ke Dinas Pendidikan Kabupaten Bengkalis, dengan persyaratan sesuai kriteria yang ditetapkan.

Panitia yang ditunjuk untuk menyeleksi dan memverifikasi proposal beasiswa tidak sama dengan panitia pelaksana. Panitia pelaksana mencakup pembina, penanggung jawab,ketua, wakil ketua, sekretaris, dan beberapa anggota. Panitia pelaksana di pegang oleh pejabat eselon dua, tiga, dan staf golongan tiga sebagai anggota. Hal ini sesuai dengan dokumen pengguna anggaran.

Panitia tim seleksi telah dipilih dari beberapa bidang dan pekerjaan nya diawasi oleh panitia pelaksana. Idealnya sebagai panitia harus mengerti bahwa program beasiswa komunitas adat terpencil memiliki kriteria yang mereka harus ketahui sebelum bekerja. Hal ini dipahami baik oleh semua panitia karena sebelum memulai penyeleksian mereka telah dikumpulkan disuatu ruangan rapat untuk mendapatkan bimbingan teknis cara dan peraturan-peraturan untuk memverifikasi proposal beasiswa.

Disimpulkan bahwa, sumberdaya manusia yang menjadi panitia telah sesuai dengan panduan teknis program beasiswa khusus 2016. Panitia mengerti tentang tupoksinya sebagai panitia prgram beasiswa komunitas Mahasiswa dari komunitas adat terpencil sangat berpengaruh dalam program beasiswa karena mereka sebagai tujuan dan sasaran program beasiswa komunitas adat terpencil.

\section{b. Sarana dan prasarana}

Fasilitas sarana dan prasarana yang digunakan pada pelaksanaan program beasiswa telah disiapkan oleh panitia pelaksana administrasi kegiatan.sarana berupa alat tulis, pena, kertas dan lainn. Pada aspek input sarana pada program beasiswa komunitas adat terpencil ini yang perlu dievaluasi adalah ruang kerja yang memadai. Karena ruangan yang digunakan untuk bekerjaadalah bidang pendidikan menengah sebagai tempat panitia untuk bekerja menyeleksi berkas permohonan mahasiswa. Selanjutnya untuk mempermudah pekerjaan, panitia pelaksana administrasi kegiatan telah mencetak lembaran pemeriksaan yang sesuaimm.;hGv ZZ; dengan kriteria-kriteria calon penerima beasiswa untuk diberikan kepada tim seleksi beasiswa komunitas adat terpencil di dinas pendidikan Kabupaten Bengkalis.

Secara keseluruhan pada aspek input sarana dan prasarana pelaksanaan program beasiswa komunitas adat terpencil ini masih perlu ditinjau kembali untuk kenyamanan dan kelayakan untuk dapat berlangsungnya dengan baik proses seleksi sehingga tercapainya tujuan utama diselenggarakannya program beasiswa komunitas adat terpencil.

\section{c. Pengelolaan Keuangan}

Juknis beasiswa khusus tahun 2016 telah menjelaskan bahwa sumber dana untuk pembiayaan program bantuan beasiswa dari APBD Kabupaten Bengkalis tahun anggaran 2016 yang dialokasikan dalam Dokumen penggunaan anggaran-SKPD bidang pendidikan menengah tahun anggaran 2016 pada mata anggaran nomor: 1.01.1.01.01.17.099.5.2.

Dari dokumen laporan keuangan telah terjadi penurunan jumlah dana yang diterima oleh mahasiswa penerima beaisiswa, tetapi terjadi peningkatan jumlah pelamar beasiswal. Sehingga peneliti mengajukan pertanyaan kepada Panitia 
pelaksana administrasi kegiata dan dia mengatakan bahwa "dana yang ditetapkan didalam DPA tidak ada peningkatan sementara jumlah permohonan beasiswa yang meningkat. jadi dana itu kita bagi sesuai aturannya. Maka jumlahnya tidak sebesar tahun lalu.” Dari keterangan diatas dapat ditarik kesimpulan bahwa pengelolaan keuangan sesuai dengan ketentuan juknis.

\section{Evaluasi Aspek Proses Pelaksanaan} Program Beasiswa Komunitas Adat Terpencil Di Dinas Pendidikan Kabupaten Bengkalis.

Aspek proses yang akan dievaluasi pada pelaksanaan program beasiswa komunitas adat terpencil di dinas pendidikan kabupaten bengkalis diantaranya adalah mekanisme pelaksanaan dan mekanisme pelaksanaan, serta faktor penghambat dalam pelaksanaan program beasiswa komunitas adat terpencil.

Juknis beasiswa khusus tahun 2016 telah mengatur jadwal pelaksanaan program beasiswa KAT seperti di bab IV table 4.5.tentangJadwal Pelaksanaan Program Beasiswa Komunitas Adat Terpencil di Dinas Pendidikan Kabupaten Bengkalis.Dijelaskan oleh kepala dinas pendidikan yang diwakili oleh kepala bidang pendidikan menengah bahwa jadwal pembayaran beasiswa terlambat dari jadwal sebenarnya. Beasiswa dapat disalurkan bulan desember tahun 2016.

yang menyebabkan pelaksanaan ini sedikit meleset dari jadwal yang ada di juknis nya yaitu masalah pencairan dana, terbentroknya dengan kegiatan-kegiatan yang penting seperti pelaksanaan ujian nasional, penerimaan siswa baru dan lain-lain.

Mekanisme pelaksanaan sudah dijalankan sesuai aturan yang terdapat dalam juknis beasiswa Meneliti persyaratan administrasi calon penerima beasiswa,Melakukan verifikasi dan seleksi calon penerima beasiswa;Mengusulkan daftar calon penerima beasiswa ke Dinas Pendidikan Kabupaten Bengkalis, Menyeleksi calon penerima beasiswa sesuai criteria, Mengusulkan daftar calon penerima beasiswa ke Dinas Pendidikan Kabupaten Bengkalis; dengan persyaratan sesuai kriteria yang ditetapkan.

4. Evaluasi Aspek Produk Pada Program Beasiswa Komunitas Adat Terpencil di Dinas Pendidikan Kabupaten Bengkalis.

a. Hasil Yang Diperoleh Mahasiswa

Adapun hasil dari pelaksanaan program beasiswa komunitas adat terpencil di Dinas Pendidikan Kabupaten Bengkalis adalahmahasiswa dari golongan Komunitas adat terpencil dapat mengikuti perkuliahan dengan dana pendidikan di bantu oleh pemerintah. Semakin banyak yang berminat untuk kuliah akan menumbuhkembangkan pemikiran bagi masyarakat KAT yang lain. Buktinya banyak anak komunitas adat terpencil yang menjadi mahasiswa yang awalnya minat melanjutkan pendidikan ke perguruan tinggi hanya sedikit. kini setiap tahunnya sudah meningkat.

\section{SIMPULAN DAN SARAN}

Berdasarkan dari data pembahasan hasil evaluasi dan analisis data yang ditilis oleh peneliti dapat disimpulkan bahwa pelaksanaan evalusai program beasiswa komunitas adat terpencil (KAT) di Kabupaten Bengkalis dikategorikan baik. Hanya saja ada beberapa hal yang harus di perbaiki yaitu, Hal tersebut dijelaskan sebagai berikut:

1. evaluasi konteks (context) pada pelaksanaan valuasi program beasiswa komunitas adat terpencil (KAT) dikabupaten bengkailis dikatakn baik. Karena dilihat dari latar belakang yang menjadi dasar utama penyelenggaraaan tersebut adalah untuk mensejahtrakan masyarakat komunitas adat terpencil.

2. input (masukan)pelaksanan program evaluasi program beasiswa komunitas adat terpencil (KAT) di Dinas Pendidikan Kabupaten Bengkalis dikatakan cukup baik, dilihat dari kelayakan sumber daya manusia yang sudah mengerti dan menjalankan 
program dengan baik. Sementara itu sarana dan prasarana harus mendapat perbaikan untuk tingkat keamanan dan kenyamanan.

3. output (hasil/keluaran/produk) pelaksanaan program evaluasi program beasiswa komunitas adat terpencil (KAT) dikabupaten bengkalis dikatakan baik karena jumlah penerima beasiswa sudah sesuai dengan juknis yang ditetapkan. Dan ketika menghadapi masalah dan tuntutan masyarakat Dinas Pendidikan Kabupaten Bengkalis bias menjelaskan dan menyelesaikannya dengan baik .

\section{Saran}

Secara keseluruhan pada penelitian ini penulis merekomendasikan bahwa program beasiswa komunitas adat terpencil di Dinas Pendidikan Kabupaten Bengkalisini dapat mewujudkan kearah perbaikan pada pendidikan di indonesia dimana setiap masyarakat berhak mendapatkan pendidikan tanpa terkecuali. Hasil dari penelitian ini juga penulis pekomendasikan bahwa sistem manajemen pada evaluasi program beasiswa komunitas adat terpencil (KAT) ini sudah berjalan dengan baik, maka untuk kedepanya pengelola dapat mempertahankan sistem ini dengan baik atau lebih baik lagi secara berkesinambungan.

\section{DAFTAR PUSTAKA}

Arikunto, Suharsimi. 2010. Evaluasi Program Pendidikan. Bumi Aksara, Jakarta.

Dunn, William N. 2000. Pengantar Analisis Kebijakan Publik. Gajah Mada University Press.

Khadijah, 2011, Jurnal “ Pemngmbangan sistem informasi seleksi beasiswa unggulan P3SWOT Kemdiknas online menggunakan Unified Process", Diponegoro

Richart L, Daft. 2010. Era Baru Manajemen. Salemba empat, Jakarta.

Sudijono, Anas. 2001. Pengantar evaluasi pendidikan. RajaGrafindo, Jakarta

Slameto. 1988. Evaluasi Pendidikan. Bumi Aksara, Salatiga.
Tayipnapis, Farida Yusuf. 2008. Evaluasi Program dan Instrumen Penelitian. Rineka Cipta, Jakarta.

Thoha Chabib. 2003. Teknik Evaluasi Pendidikan, Raja Grafindo Persada,Jakarta Wirawan. 2011. Evaluasi, teori, model, standar, aplikasi dan profesi. Rajawali Press, Jakarta.

Widoyoko, Eko Putro, 2014. Model Evaluasi Program Pendidikan Pembelajaran IPS di SMP, diakses pada tanggal 20 Juli 2014

Collit, 2002. The CIPPApproach To Evaluation, http://www.fivwhokies.com/Evaluation/ Evaluation\%20Approaches $/$ Management\%20oriented/ CIPP\%20Approach\%20to\%Evaluation.pdf. Diakses tanggal 2 januari 2015.

Abraham s fischler, 2011. Program Evaluasi, an overview, schoool of education. Sourthern university.

Arifin zainal, 2010. Model-model Evaluasi progam, Makalah, UPI. Bandung. 2010 . Evaluasi program, UPI, Bandung.

Daniel L. Stufflebeam, 2007. CIPP Evaluations Mpdel cheklist, NSF.

Gray Rees and Ray french. 2010. Leading, managing and developing people, 3rd edition, published by the CIPID,UK.

Peraturan mentri nomor 22 tentang standar isi.

Peraturan mentri pendidikan nasional republik indonesia nomor 14 tahun 2007

Peraturan mentri pendidikan nasional republik indonesia nomor 23 tahun 2006.

Peraturan mentri pendidikan nasional republik indonesia nomor 24 tahun 2006

Suharsimi arikunto \& abdul jabar (2009). Evaluasi program pendidikan: pedoman teoritis prakts bagi mahasiswa dan praktisi pendidikan. Edisi kedua. Jakarta: PT. Bumi aksara

Undang-undang nomor 20 tahun 2003, tentang sistem pendidikan nasional. 